\title{
Exploring MAS: A Reliable Molecular tool for Development of Multiple Disease Resistance in Tomato (Solanum lycopersicum L.) through Gene Pyramiding
}

\author{
John Oladeji Oladokun ${ }^{1}$, Immaculate Mugisa ${ }^{2,3}$
}

\author{
${ }^{1}$ Department of Plant Pathology, Faculty of Agriculture Assam Agriculture University, Jorhat, Assam, India; \\ ${ }^{2}$ Makerere University, Regional Centre for Crop Improvement (MaRCCI), Uganda \\ ${ }^{3}$ Mukono Zonal Agricultural Research and Development Institute (MUZARDI), National Agricultural Research \\ Organization, Kampala, Uganda
}

\begin{abstract}
Tomato is principally subjected to severe yield losses due to adverse effects of a number of factors particularly biotic factors (pathogens). The lacks of tomato genotypes resistance to diseases have increased both the financial cost and environmental impact of tomato production while reducing the yield and quality. Therefore developing tomato genotypes with multiple resistances to diseases is a desirable goal. However, the most effective strategy of controlling reduction in yield and quality of tomato caused by various biotic factors during crop productivity encountered by poor resource farmers is by utilization of host resistance. Recently, technological advancement has led to the development of DNA based molecular markers closely linked to genes in tomato chromosomes that bestowed resistance to various kinds of biotic factors. Gene transfer of preferred traits into a single tomato genotype is now possible through the deployment of marker assisted selection (MAS) process, which now hastens the advancement of resistance tomato cultivars in its lowest population with gene pyramiding or stacking. In this review, we present the eco-friendly molecular tools with emphases on MAS for the improvement of biotic resistance in tomatoes which can be more explore in identifying land races that have the potentials of subduing the attack of pathogens if improved genetically.
\end{abstract}

Keywords-Disease resistance, gene pyramiding, Tomato, Marker Assisted Selection (MAS).

\section{INTRODUCTION}

Tomato (Solanum lycopersicum L.) is cultivated as a major fruit and vegetable crop both in the tropics and subtropics of the world and is of great economic importance to many smallholder farmers as well as consumers. When eaten either fresh or in processed form, it supplies vitamin $\mathrm{A}$ and $\mathrm{C}$ in the human diet and equally serves as an antioxidant which protects cells from oxidants that have been linked to cancer (Giovannucci, 1999; Agarwal and Rao, 2000; Rao and Rao, 2007). The less effort required in tomato cultivation compared to other crops and the short maturity duration of most tomato genotypes; could have led to the appreciable number of smallholders increasing their initial cultivable land areas thereby changing from subsistence farming to commercial cultivation.

Generally, low yield of tomatoes are due to a number of factors, that is, biotic, abiotic, or their natural genetic composition. These factors include, lack of appreciable number of improved well-performing varieties or genotypes, poor fruit setting due to heavy rains and excessively high temperatures; which limit pollination, more specifically fecundation plus pollen viability; pests and diseases (Villareal, 1979; Lyons et al., 1985; Ladipo, 1988). However, diseases caused by pathogens such as fungi, bacteria, viruses and nematodes have been playing significant roles in reduction of potential yield of many tomato varieties either directly or indirectly for many years as evident from reports in literature. Management approaches to reduce or mitigate the extent of damage caused by these pathogens in the past have mainly through manipulation of the environment through cultivation practices (such as intercropping, mixed cropping systems, crop rotation and so on), which prevent an increase in the disease causal agents of infection. The use of Agrochemicals has also been encouraged in the past but this approach is not eco-friendly and also poses many health 
problems in addition to their adverse effect it might possibly caused on fruit quality. Chemical control is also known to give good results for some pathogens, but poor results against others, such as bacteria, and practically no effects on viruses.

It is noteworthy that technological advancement in innovative genetic preferences and breeding for pathogenplant resistance in tomato is a cost effective and feasible option to that can contribute to yield in an eco- friendly environment. Since the domestication of many plants including tomato, differences in varietal response to various stresses have been observed (Ragimekula et al., 2013). The emergence of new strains of pathogens necessitates development of highly improved approaches to enhance the capability of tomato varieties to survive numerous pathogen attacks at once. In cultivated tomato generally, there is absence of resistance in their gene pools and so, effort has been to identify host resistance against diseases in wild tomato species in the last decades (Zamir et al., 1994; Ji et al., 2007, 2009; Hanson et al., 2006; Garcia et al., 2007; Anbinder et al., 2009).

Through conventional breeding programmes along with desired genes of interest, other genes also continue to the next filial generations, which make screening a difficult task in conventional breeding techniques. In spite of their drawbacks, conventional breeding techniques are also important for the conservation of wild type germplasms, hybridization between opposite parental lines and so on.

Today, for continued yield improvement, new technologies especially the use of DNA molecular markers, currently serve as a new technological tool to detect the presence of allelic variation in the genes underlying the economic traits in tomato varieties. DNA markers have enormous potential to improve the efficiency and precision of conventional breeding through marker-assisted selection (MAS) by reducing the reliance on laborious and fallible screening procedures (Ragimekula et al., 2013). The technique enables the transfer of desired genes of interest in tomato with appropriate combination. This short review therefore, briefly highlights the molecular markers presently available for breeding programs in tomato with classical examples of successful results where genes/loci from resistant tomatoes have been pyramided into other susceptible tomato elite. We also give suggestions for further research work in this area crop productivity.

\section{MARKER ASSISTED SELECTION: A MOLECULAR TOOL IN TOMATO BREEDING}

MAS are a technological based process by which a marker is indirectly used for the selection criteria of genetic factor(s) or determinants of a trait including disease tolerance. It is used as a substitute for or to assist phenotypic screening. It involves selecting plants carrying traits of interest in the genomic regions expressing the traits through the use of molecular markers. Basically, selection of plants using MAS is based on the genotype of the as sociated markers rather than the traits. But the success of using MAS depends on many other factors, including the underlying genetic control of the trait(s) of interest (Foolad and Panthee, 2012). With the advent of MAS in tomato breeding programs, its application enables individual plants to be selected based on their genotypic characteristics during the selection process. Since, heterozygotes cannot be easily distinguished from homozygotes through conventional breeding, MAS can be used instead to achieve this purpose by selecting parents and as well increase the chance of backcrossing for reliable linkages between markers and traits of interest such as disease resistance, and fruit quality. Furthermore, MAS can be used to investigate heterosis for hybrid crop production (Reif et al., 2003).

There are many more advantages of using MAS in tomato breeding, for example, in testing seed purity of large lots of tomato, quick germplasm screening for disease resistance or fruit quality (Foolad and Panthee, 2012). This is because it is simpler than phenotypic screening, reduces time, effort to employ and resources to be used. Additionally, MAS can be done at the seedling stage by eliminating undesirable plant genotypes even when dealing with traits that seem to be complex.

\section{MOLECULAR MARKERS USED IN TOMATO BREEDING}

The progress in plant breeding is now easy and quick for qualitative traits controlled by major genes with easily identifiable effects on phenotype unlike quantitative characters which is still more complicated. The use of molecular tools has significantly improved tomato breeding programs, allowing application of advanced molecular breeding techniques in tomato that have led to the improvement of cultivable tomato varieties that are resistant to diseases. Through MAS, this objective has been achieved over the years. Fortunately, tomato was one of the first crops for which molecular markers were suggested as indirect selection criteria for breeding purposes (Rick and 
Fobes, 1974; Tanksley and Rick, 1980; Tanksley, 1983). However, with the development of new molecular markers and maps in tomato, MAS has become a routine practice in many tomato breeding programs, in particular in the private sector, for several purposes including (1) to assess hybrid purity from overseas production by screening seed lots with a panel of molecular markers, (2) for quick and effective germplasm screening for disease resistance or fruit quality and (3) for marker assisted backcrossing (MAB) after reliable linkages between markers and simple traits of interest are discovered (Foolad and Panthee 2012). Most of the molecular markers used in tomato breeding programs use the polymerase chain reaction (PCR). These markers are all DNA based techniques designed to detect and exploit naturally occurring DNA polymorphisms which provides a unique type of markers to serve as an index of genetic worth of the entire genome. The main consideration for the use of DNA markers in MAS is that, markers should be tightly linked to target loci or genes preferably less than 5 centimorgan genetic distances.

Several DNA based molecular markers have been used in breeding for tomato biotic stress resistance as evident from various literatures (Table 1). These molecular markers include, restriction fragment length polymorphism (RFLP), random amplified polymorphic DNA (RAPD), microsatellites or simple sequence repeat (SSR), cleaved amplified polymorphic sequence (CAPS), single nucleotide polymorphism (SNP) and Sequence Characterized Amplified Region (SCAR). Depending on research and interest needs, each suitable molecular marker of preference in any tomato breeding program must fulfill the following conditions that characterize its suitability: (1) must be polymorphic, (2) display co-dominant inheritance, (3) randomly and frequently distributed throughout the genome, (4) easy and cheap to detect and (5) should be reproducible. However, PCR-based markers are more attractive for MAS, due to the small amount of DNA template required and more efficient handling of large population sizes (Ragimekula et al., 2013). With the advent of these molecular markers, their applications in tomato breeding have been useful in: (1) early generation selection of trans gres sive segregants to increase the speed and efficiency of developing new varieties, (2) introgression of genes from wild type, (3) gene pyramiding, which is of emphases of this review (4) DNA fingerprinting of tomato varieties to characterize genetic diversity for effective management and utilization of germplasm resources, (5) construction of high saturated (density) maps of tomato crop that provides assessment of segment of genome for economic use, and so on. Hence, the steps to follow for gene pyramiding scheme using MAS are described in (Fig.1a, b) respectively.

\section{GENE PYRAMIDING USING MAS: AN EXCELLENT APPROACH IN TOMATO BREEDING PROGRAMS}

Gene pyramiding or preferably gene stacking in tomato involves the transfer or pyramiding of more than one gene resistance or tolerance to a particular disease (s) into a single tomato genotype (Fig. 1b). Since there are likely chances of each resistance gene to be overcome by a new virulent race (VR), there is need to place all available major genes of VR into a single genotype which will reduces the probability of a new race conferring virulent genes at all the corresponding loci. And so, to achieve this objective, gene pyramiding is an essential technique to be adopted. This breeding methodology combines both the conventional (artificial hybridization) and molecular techniques in improving new tomato genotypes carrying the genes of interest. Pyramiding of resistance genes into a single line for each disease is a strategy to prevent the breakdown of resistance against specific disease (s). Such genes are found mostly in the wild types of tomato varieties. Basically, with the introduction of MAS, plant breeders now make use of this technique to confer resistance by several different genes or loci with the help of markers that are closely linked against such diseases like Tomato leaf curl virus disease (TLCV), Tomato spotted wilt virus (TSWV), Bacterial spot, Bacterial speck diseases, late blight, Fusarium wilt and so on (Table 1). To obtain the desired population with required gene combinations without unwanted genes, it is essential to make some backcrossing with the recurrent parent (Fig. 1b). With the help of molecular markers linked to the gene, selection of tomato progenies with desired traits in a population are easily identified for several effective backcrossing schemes whereas progenies not carrying the conferred gene are discarded. Gene pyramiding helps in development of a pedigree designed to accumulate all desired genes in a single genotype and as well fix the target genes into a homozygous state to derive the ideal genotype from one single genotype (Fig.1b).

\section{CONCLUSIONS}

There are several biotic factors that affect the productivity of tomato. But the present development of molecular markers has led to an increase in the use of disease resistant quantitative trait loci (QTL) in tomato breeding. Gene pyramiding is an important breeding strategy for tomato and 
improvement of germplasm of agricultural crops, but requires that breeders should consider the minimum population size that must be evaluated to have a chance of obtaining the desired genotype. Considerably, molecular marker genotyping can facilitate the process by reducing the number of generations that breeders must evaluate to ensure that they have the desired gene(s) combination introgress ed to the desired genotype of interest. Hence, in order to reduce the risks of pathogen adaptation, resistance breeding schemes through the use of MAS by gene pyramiding should be more thoroughly explored with deployment strategies of resistant genotypes and combination strategies of diverse disease control methods. Since the use of MAS has made it possible to identify and select tomato plants with different numbers of resistance genes with related resistance performance, hence, exploring diverse tomato genotypes genome should be intensified. However, to pyramid multiple resistance genes into a single cultivar of tomato, tomato breeders should be able to monitor the effects of the genes stacked in the same cultivar, which is not readily possible through phenotypic measurements. Therefore through the use of marker assisted pyramiding in tomato breeding programs, breeding for qualitative disease resistance has been proven to be useful and should be effectively utilized on tomato germplasms that have high yielding ability but with significant rate of susceptibility to pathogens.

\section{ACKNOWLEDGEMENTS}

This article contains information gathered from published and unpublished resources, and so, we would like to extend our appreciations to all authors whose references were used in this manuscript.

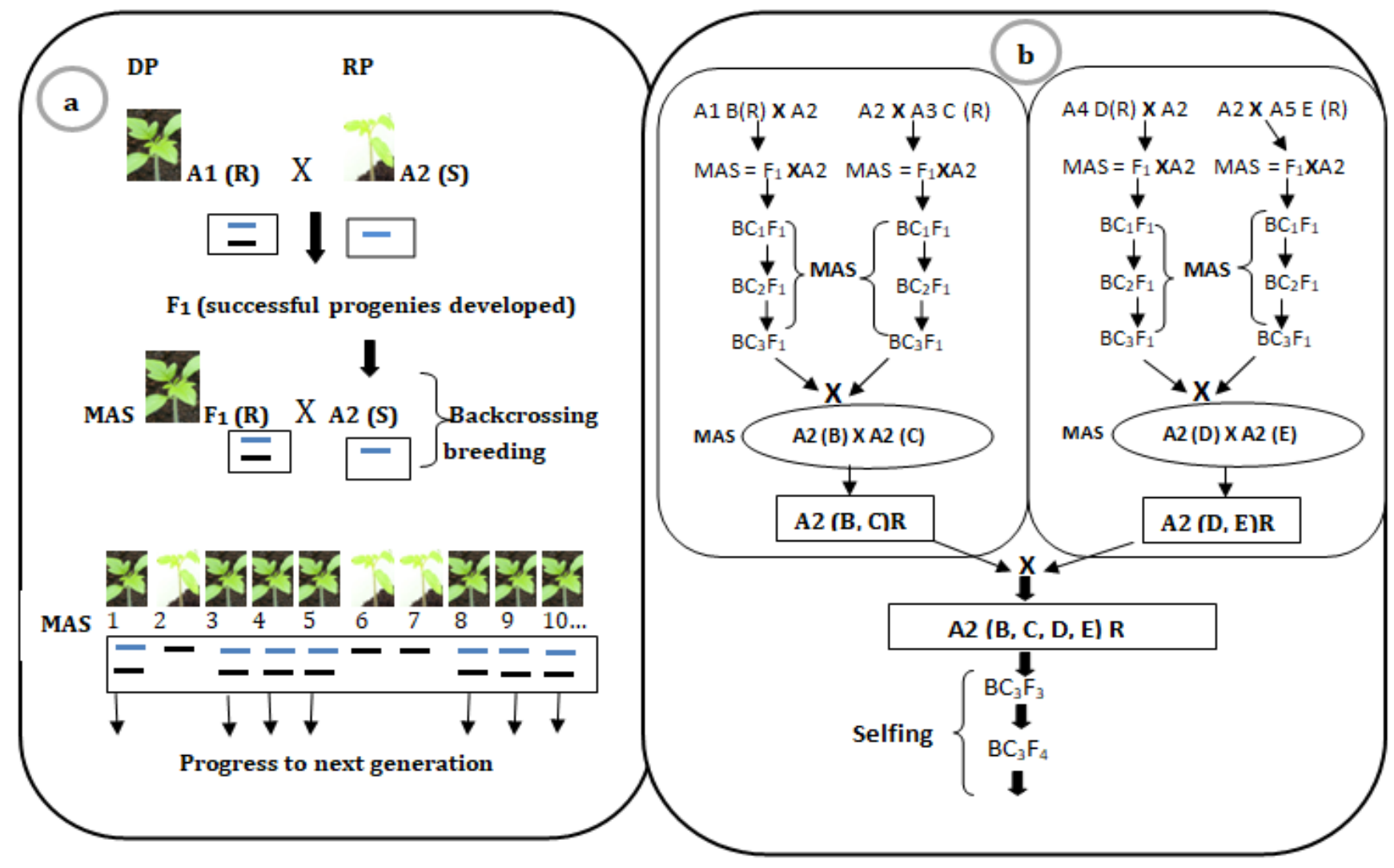

Fig.1 (a) General overview of marker assisted backcross in a tomato breeding program; DP (donor parent); RP (recipient parent); $X$ (crosses); $R$ (Resistant genotype); $S$ (Susceptible genotype); A1,B,C,D,E (represents different tomato genotypes resistant to different diseases; $A 2$ ( high yielding genotype but susceptible to A1,B,C,D,E) (b) Basic flow diagram showing steps involved in gene pyramiding of multiple biotic resistance $(R)$ genes into a single genotype using marker assisted backcross breeding. 


\begin{tabular}{|c|c|c|c|c|c|}
\hline Traits pyramided & Gene/QTL(s) & $\begin{array}{c}\text { Genotype (s) improved } \\
\text { by pyramiding }\end{array}$ & Donor Parent(s) & $\begin{array}{l}\text { Type of available } \\
\text { linked markers }\end{array}$ & Reference \\
\hline $\begin{array}{c}\text { Tomato yellow leaf } \\
\text { curl virus } \\
\mathrm{X} \\
\text { Tomato spotted wilt } \\
\text { virus }\end{array}$ & $T y-1, T y-3, S w-5$ & Cuban tomato (LD3) & LA2779, LA1969, & $\begin{array}{c}\text { CAPS, RAPD }(E c o \text { R1 }), \\
\text { SCAR, }\end{array}$ & Consuegra et al., 2015 \\
\hline $\begin{array}{l}\text { Tomato yellow leaf } \\
\text { curl virus } \mathrm{X} \\
\text { Tomato mottle virus }\end{array}$ & $T y-1, T y-3$ & LA2779 & LA1932, LA1938 & $\begin{array}{c}\text { CAPS, RAPD(EcoR1), } \\
\text { SCAR, }\end{array}$ & Ji et al., 2007 \\
\hline $\begin{array}{c}\text { Late blight X } \\
\text { Tomato yellow leaf } \\
\text { curl virus X } \\
\text { Bacterial } \\
\text { wilt X Fusarium } \\
\text { wilt X Gray leaf } \\
\text { spot X Tobacco } \\
\text { mosaic virus }\end{array}$ & $\begin{array}{c}\text { Bwr-12, Ty-2, Ty-3, } \\
T m 2^{2}, P h-2, P h-3 \\
S m\end{array}$ & CLN3241 & CLN2777G, G2-6-20-15B, LBR-11 & CAPS, SCAR & Hanson et al., 2016 \\
\hline $\begin{array}{l}\text { Fusarium wilt } \mathrm{X} \\
\text { Late blight }\end{array}$ & $I 1, P h-3$ & $\begin{array}{c}\text { Accession } 1008 \\
017878,107868 \\
0101 \text { and } 1002\end{array}$ & Not defined & SSR , SCAR & Akbar et al., 2016 \\
\hline $\begin{array}{l}\text { Bacterial spot } \mathrm{X} \\
\text { Bacterial speck }\end{array}$ & Pto, $R x 3$ & Crosses between parents & Ohio 9834 , Ohio 8819 , Ohio 981205 & CAP $(R s a 1, B s r B 1)$ & Yang and Francis, 2005 \\
\hline $\begin{array}{c}\text { Tomato yellow leaf } \\
\text { curl viruses } \\
\text { (monopartite and } \\
\text { bipartite) }\end{array}$ & $T y-2, T y-3$ & $\begin{array}{l}\text { Crosses between: } \\
\text { FLA478-6-1-11 and } \\
\text { CLN2498C,CLN1621E }\end{array}$ & $\begin{array}{c}\text { Ty- stock of: } \\
\text { LA3473,CLN2585D,CA4,GC171, } \\
\text { TY-172 }\end{array}$ & CAPS, SCAR, SSR & Prasanna et al., 2014 \\
\hline $\begin{array}{l}\text { Tomato spotted wilt } \\
\text { virus X Late blight }\end{array}$ & $S w-5, P h-3$ & $\begin{array}{c}\text { Crosses between NC946 } \\
\text { and NC592 }\end{array}$ & NC946, NC592 & CAPS , SCAR & Robbins et al., 2010 \\
\hline $\begin{array}{l}\text { Tomato leafcurl } \\
\text { virus }\end{array}$ & $T y-1, T y-2$ & $\begin{array}{l}\mathrm{Pbc}, \mathrm{H}-86 \text { crosses with } \\
\text { the parents }\end{array}$ & EC538408, EC520061, H-24 & CAPS, SSR & Kumar et al., 2014 \\
\hline
\end{tabular}




\begin{tabular}{|c|c|c|c|c|c|}
\hline Traits pyramided & Gene/QTL(s) & $\begin{array}{l}\text { Genotype (s) improved } \\
\text { by pyramiding }\end{array}$ & Donor Parent(s) & $\begin{array}{l}\text { Type of available } \\
\text { linked markers }\end{array}$ & Reference \\
\hline $\begin{array}{c}\text { Tobacco mosaic } \\
\text { virus X Fusarium } \\
\text { wilt X Root-knot } \\
\text { nematode disease X } \\
\text { Leaf mildew }\end{array}$ & $\begin{array}{l}T M-2^{a}, I-2, M i-1 \\
C f-9\end{array}$ & L11, L19, L46 and L51 & Longkeeper, Jia Powder & CAPS & Zhu et al., 2010 \\
\hline $\begin{array}{l}\text { Phytophthora } \\
\text { infestans }\end{array}$ & $P h-2 *$ & $\begin{array}{c}\text { AD17, } 137, \text { P15250, } \\
\text { SeI8 }\end{array}$ & $\begin{array}{l}\text { Heline, Momor, Motelle, Ontario, } \\
\text { Pyrella, Stevens }\end{array}$ & & \multirow{6}{*}{$\begin{array}{c}\text { Barone A ( Not yet } \\
\text { published .See reference } \\
\text { section for link to this } \\
\text { information) }\end{array}$} \\
\hline $\begin{array}{c}\text { Fusarium } \\
\text { oxysporiumf.sp. } \\
\text { radicis-lycopersici } \\
\mathrm{X} \\
\text { Tobacco mosaic } \\
\text { virus X Verticillium } \\
\text { dahliae }\end{array}$ & Frl $, T M-2^{a}, V e^{*}$ & $\begin{array}{c}\text { AD17, 137, P15250, } \\
\text { SeI8 }\end{array}$ & $\begin{array}{c}\text { Heline, Momor, Motelle, Ontario, } \\
\text { Pyrella, Stevens }\end{array}$ & CAPS & \\
\hline $\begin{array}{c}\text { Fusarium } \\
\text { oxysporium } f . \mathrm{sp} . \\
\text { lycopersici } \\
\text { X Meloidogyne spp. } \\
\text { X Verticillium } \\
\text { dahliae }\end{array}$ & $I 2^{*}, M i, V e^{*}$ & $\begin{array}{c}\text { AD17, 137, P15250, } \\
\text { SeI8 }\end{array}$ & $\begin{array}{c}\text { Heline, Momor, Motelle, Ontario, } \\
\text { Pyrella, Stevens }\end{array}$ & CAPS & \\
\hline $\begin{array}{l}\text { Pseudomonas } \\
\text { syringae }\end{array}$ & Pto & $\begin{array}{c}\text { AD17, 137, P15250, } \\
\text { SeI8 }\end{array}$ & $\begin{array}{c}\text { Heline, Momor, Motelle, Ontario, } \\
\text { Pyrella, Stevens }\end{array}$ & CAPS & \\
\hline $\begin{array}{l}\text { Pyrenochaeta } \\
\text { lycopersici }\end{array}$ & py-1 & $\begin{array}{l}\text { AD17, 137, P15250, } \\
\text { SeI8 }\end{array}$ & $\begin{array}{c}\text { Heline, Momor, Motelle, Ontario, } \\
\text { Pyrella, Stevens }\end{array}$ & SCAR & \\
\hline $\begin{array}{c}\text { Tomato spotted wilt } \\
\text { virus }\end{array}$ & $S w-5$ & $\begin{array}{c}\text { AD17, } 137, \text { P15250, } \\
\text { SeI8 }\end{array}$ & $\begin{array}{c}\text { Heline, Momor, Motelle, Ontario, } \\
\text { Pyrella, Stevens }\end{array}$ & CAPS & \\
\hline
\end{tabular}

$*$ = Search for the suitable markers is still in progress as reported by Barone $\mathbf{A}$ 


\section{REFERENCES}

[1] Agarwal, S., Rao, A.V. (2000). Tomato lycopene and its role in human health and chronic diseases. Can. Med. Assoc. J. 163, 739-744.

[2] Akbar, K., Abbasi, F.M., Sajid, M., Ahmad, M., Khan, Z.U., Aziz-Ud-Din. (2016). Marker-assisted selection and pyramiding of $\mathrm{I} 1$ and $\mathrm{Ph} 3$ genes for multiple disease resistance in tomato through PCR analysis. Int. J. Biosci. 9 (3), 108-113.

[3] Anbinder, I., Reuveni, M, Azari R, Paran I, Nahon, S. (2009). Molecular dissection of Tomato leaf curl virus resistance in tomato line TY172 derived from Solanum peruvianum. Theory of Applied Genetics 119, 519-530.

[4] Barone, A. Molecular marker-assisted selection for resistance to pathogens in tomato Available : https://pdfs.semanticscholar.org/cb39/fbc9353476b536 b244738490709551a92de4.pdf

[5] Consuegra, O.G., Gómez, M.P., Zubiaur, Y.M. (2015). Pyramiding TYLCV and TSWV resistance genes in tomato genotypes. Rev Protección Veg. 3 (2), 161-164.

[6] [6] Foolad, M.R., Panthee, D.R. (2012) Markerassisted selection in tomato breeding. Critical Reviews in Plant Sciences 31, 93-123. http://dx.doi.org/10.1080/07352689.2011.616057

[7] Garcia, B.E., Graham, E., Jensen, K.S., Hanson, P., Mejia, L. 2007). Co-dominant SCAR marker for detection of the begomovirus-resistance Ty-2 locus derived from Solanum habrochaites in tomato germplasm. Rep. Tomato Genet Coop 57, 21-24.

[8] Giovannucci, E. (1999). Tomatoes, tomato-based products, lycopene, and cancer; Review of the epidemiologic literature. J. Natl. Cancer Inst. 91, 317-331.

[9] Hanson, P., Lu, S., Wang, J., Chen, W., Kenyon, L., Tan, C., Tee, K.W., Wang, Y., Hsu, Y., Schafleitner, R., Ledesma, D., Yang, R. (2016). Conventional and molecular marker-assisted selection and pyramiding of genes for multiple disease resistance in tomato. Scientia Horticulturae 201, 346-354.

[10] Hanson, P., Green, S.K., Kuo, G. (2006). Ty-2, a gene on chromosome 11 conditioning geminivirus resistance in tomato. Tomato Genet Coop Rep 56, 1718.

[11] Ji, Y., Scott, J.W., Schuster, D.J. (2009). Toward fine mapping of the Tomato yellow leaf curl virus resistance gene $T y-2$ on chromosome 11 of tomato. HortScience 44, 614-618.
[12] Ji, Y., Schuster, D. J., Scott, J.W. (2007). Ty-3, a Begomovirus resistance locus near the Tomato yellow leaf curl virus resistance locus Ty-1 on chromosome 6 of tomato. Mol. Breed. 20, 271-284.

[13] Kumar, A., Tiwari, K.L., Datta, D., Singh, M. (2014). Marker assisted gene pyramiding for enhanced Tomato leaf curl virus disease resistance in tomato cultivars. Biologia Plantarum 58 (4), 792-797

[14] Ladipo, J.I. (1988). Viruses of Vegetable Crops in Africa. In, Alufi W., Mbiele, A.L., Nkonka N. 1988. Virus diseases of plants in Africa. Scientific publication pp. 157-164

[15] Lyons, J.M., Ferris, H. (1985). IPM for Tomatoes. University of California, Statewide IPM. Project Publication No. 3274

[16] Prasanna, H.C., Sinha, D.P., Rai, G.K., Krishna, R., Sarvesh, P.K., Singh, N.K., Sing, M., Malathi, V.G. (2014). Pyramiding Ty-2 and Ty-3 genes for resistance to monopartite and bipartite tomato leaf curl viruses of India. Plant Pathology 64 (2), 256-264. http: //doi: 10.1111/ppa.12267

[17] Ragimekula, N., Varadarajula, N.N., Mallapuram, S.P., Gangimeni, G., Reddy, R.K.., Kondreddy, H.R. (2013). Marker assisted selection in disease resistance breeding. J. Plant Breed. Genet. 1 (02), 90-109.

[18] Rao, A.V., Rao, L.G. (2007). Carotenoids and human health. Pharmacol. Res 55, 207-216.

[19] Reif, J.C., Melchinger, A.E., Xia, X.C., Warburton, M.L., Hoisington, D.A., Vasal, S.K., Beck, D., Bohn, M., Frisch, M. (2003). Use of SSRs for establishing heterotic groups in subtropical maize. Theor. Appl. Genet 107, 947-957. doi: 10.1007/s00122-003-1333-x

[20] Rick, C., Fobes, J. (1974). Association of an allozyme with nematode resistance. Rep. Tomato Genet. Coop. 24, 25.

[21] Robbins, M.D., Masud, M.A.T., Panthee, D.R., Gardner, R.G., Francis, D.M., Stevens, M.R. (2010). Marker-assisted Selection for Coupling Phase Resistance to Tomato spotted wilt virus and Phytophthora infestans (Late Blight) in Tomato. Hortscience 45 (10), 1424-1428.

[22] Tanksley, S.D. (1983). Molecular markers in plant breeding. Plant Molec Biol Rep 1, 3 - 8 .

[23] Tanksley, S.D., Rick, C.M. (1980). Isozyme gene linkage map of tomato: Applications in genetics and breeding. Theor Appl Genet 57, 161-170.

[24] Villareal, R.L. (1979). Tomato production in the tropics, Problems and progress; In AVRDC, 
1979, Proceedings of the 1st International Symposium on Tropical Tomato, Shanhua, Taiwan, China, 6

[25] Yang, W., Francis, D.M. (2005). Marker assisted Selection for Combining Resistance to Bacterial Spot and Bacterial Speck in Tomato. J. Amer. Soc. Hort. Sci 130(5), 716 - 721.

[26] Zamir, D., Ekstein-Michelson, I., Zakay, Y., Navot, N., Zeidan, M., Sarfatti, M., Eshed, Y., Harel, E., Pleban, T., Oss, H.V., Kedar, N., Rabinowitch, H.D., Czosnek, H. (1994). Mapping and introgression of a Tomato yellow leaf curl virus tolerance gene, Ty-1. Theor. Appl. Genet 88, 141-146.

[27] Zhu, M., Sun, Y., Zheng, S., Zhang, X., Wang, T., Ye, Z., Li, H. (2010). Pyramiding Disease Resistance Genes by Molecular Marker Assisted Selection in Tomato. Acta Horticulturae Sinica 37(9), 1416-1422. 